A Theory of Groupwork Practice 

Also by Tom Douglas
Decade of Small Group Theory
Groupwork Practice
Basic Groupwork
Group Processes in Social Work
Groups: Understanding People Gathered Together
Group Living
Handbook of Common Groupwork Problems 


\title{
A Theory of Groupwork Practice
}

\author{
Tom Douglas
}

MACMILLAN 


\section{(C) Tom Douglas 1993}

All rights reserved. No reproduction, copy or transmission of this publication may be made without written permission.

No paragraph of this publication may be reproduced, copied or transmitted save with written permission or in accordance with the provisions of the Copyright, Designs and Patents Act 1988, or under the terms of any licence permitting limited copying issued by the Copyright Licensing Agency, 90 Tottenham Court Road, London WIP 9HE.

Any person who does any unauthorised act in relation to this publication may be liable to criminal prosecution and civil claims for damages.

First published 1993 by

THE MACMILLAN PRESS LTD

Houndmills, Basingstoke, Hampshire RG21 2XS

and London

Companies and representatives

throughout the world

ISBN 978-0-333-54874-5 ISBN 978-1-349-22601-6 (eBook)

DOI 10.1007/978-1-349-22601-6

A catalogue record for this book is available from the British Library.

$\begin{array}{lllllllll}10 & 9 & 8 & 7 & 6 & 5 & 4 & 3 & 2\end{array}$

$\begin{array}{lllllllll}03 & 02 & 01 & 00 & 99 & 98 & 97 & 96 & 95\end{array}$ 
To Shirley, as ever, for her love and constant support 


\section{Contents}

List of Tables viii

Preface ix

1 Introduction 1

2 Interactive and Affiliative Patterns in Groups 18

3 Associative Patterns in Created and Adapted Groups 29

4 Resources 49

5 Obstacles 63

6 The Techniques that Groupworkers Use $\quad 80$

7 Resource Theory 96

8 Group Design I 110

9 Group Design II 126

10 Implications 140

$\begin{array}{ll}\text { Epilogue } & 151\end{array}$

References 155

$\begin{array}{ll}\text { Index } & 162\end{array}$ 


\section{List of Tables}

1.1 Sources 3

1.2 Contributions from sources outside groupwork 10

1.3 Sources of information about groupwork 13

3.1 Group as context and as instrument 47

5.1 Obstacles to resource access and use 72 


\section{Preface}

This book attempts to address one principal issue and one secondary issue: (1) to provide a common theoretical structure for all forms of groupwork practice, and (2) to make a primary comment about the perplexing and often misunderstood problem of influence. The first is based upon either the idea of a common thread which runs through everything that groupworkers do, or, what often amounts to the same thing seen from a different viewpoint, to accept that some ideas, concepts, principles and so on are bigger, more global in scope than others and can thus contain within their general structure many ideas and practices which have arisen and are used in an independent and sometimes apparently competitive form. In either case the aim is to provide a theory of practice (what groupworkers do) which is comprehensive, logical and useful, but which does not seek to replace loyalty to specific theoretical approaches, but rather to clarify the relationship of these to a larger and logical whole.

The second and minor (in this context) issue derives from the need to make it explicit that there is no such thing as a value-free intervention technique even if that technique is apparently based upon so-called 'non-intervention'. What is at issue is not 'to be or not to be' interventionist, but how much, in what way, with what consequences and above all with what intent any form or pattern of groupwork operates.

The Heisenberg Principle of Uncertainty states that ultimate facts continually recede. Thus to expose the influence systems which operate in groupwork promotes the idea that such influences should be made visible because it is not possible to operate without them. But underlying that idea is a value (or values) which accepts that such openness is essential and under- 
neath or behind that lies another set of values which is concerned with the manner of dealing with other human beings and so on.

So, knowing this to be the case (and this knowing is one of the stages in the process), one is forced into accepting the 'As If' syndrome, as in 'I know there are more factors involved but in this case I will act as if there were not.' Thus the factor of importance is 'choice' - what can be accepted as the appropriate cut-off point. There are no certainties, though most of us act 'as if' there were, often at inappropriately 'high' levels of cut-off.

The continuum of leadership is not therefore one which ranges from directive to non-directive, but one in which the application of influence takes different forms, producing different consequences, but, it is hoped, always with the same basic intent - the development or increase of choice and self-responsibility amongst those to whom it is directed.

Tom Douglas 